\title{
PERFIL SOCIOPOLÍTICO DOS MEMBROS TITULARES DA COMISSÃO DA AGRICULTURA E REFORMA AGRÁRIA DO SENADO FEDERAL
}

\author{
SOCIOPOLITICAL PROFILE OF THE FULL MEMBERS OF THE \\ AGRICULTURE AND LAND REFORM COMISSION OF THE FEDERAL \\ SENATE
}

Wesley Rodrigues Santos Ferreira*

\begin{abstract}
Resumo
Percebe-se que há um baixo interesse em realizar estudos sobre o Senado Federal, isto deve-se ao fato de o Senado Federal assumir com frequência um papel de câmara revisora, ou seja, não é percebida, por parte da literatura, sua autonomia enquanto casa legislativa de deliberação. De igual modo, o sistema de comissões no Senado Federal é pouco explorado. O objetivo deste trabalho é contribuir para a agenda de estudos sobre o sistema de comissões do Senado Federal, realizando uma análise da composição sociopolítica da Comissão de Agricultura e Reforma Agrária (CRA) do Senado Federal. Para este fim, utilizaremos dados sobre: 1) perfil político dos membros da comissão (partido, número de mandatos no Senado e cargos políticos exercidos); 2) perfil sociodemográfico (região e gênero); e 3) seniority (nível de escolaridade, área de formação profissional, área de mandatos, atuação profissional) e expertise. Os dados referem-se ao período de 2005 a 2018, o que engloba o tempo de existência da CRA, disponibilizados no site do Senado Federal e no Relatório Anual da Presidência do Senado Federal. Dessa forma, foi possível verificar que a CRA apresenta desde sua origem, uma presença de mais de $50 \%$ de membros da coalizão de governo, atingindo cerca de $80 \%$ no segundo mandato do governo Dilma, isto é, nota-se que há um compartilhamento de poder entre os partidos membros da coalizão e o partido governista na CRA. Outrossim, foi possível inferir que a presidência e a vice-presidência foram, majoritariamente, assumidas pelos partidos da coalizão governista e o partido governista, logo, indicando pouco espaço para articulação da oposição. Observa-se também que a fragmentação partidária, verificada em plenário, refletiu-se na CRA, cujo número de partidos variou entre 8 a 11. No geral, os membros, em sua maioria, estão em primeiro ou segundo mandato, entretanto, não são políticos “inexperientes", grande parte deles já ocupou outras posições eletivas, sobretudo no Legislativo.
\end{abstract}

Palavras-chave: Senado; Estudos Legislativos; Comissão de Agricultura e Reforma Agrária.

\begin{abstract}
One notices that there a low interest in the conducting studies on the Federal Senate, due to the fact that the Senate often assumes a role of review chamber, that is, not is perceived the autonomia of the Federal Senate as legislative deliberative home. Similarly, the

\footnotetext{
* Graduando em Ciências Sociais pela UFPA/Brasil. Professor voluntário no Projeto Universidade Aberta/UFPA/Brasil. E-mail: rodrigueswesleysf@gmail.com.
} 
commission system in the Federal Senate is little explored. The objective of this work is to contribute to the agenda of studies on the system of commissions of the Federal Senate, making an analysis of the sociopolitical composition of the Committee of Agriculture and Agrarian Reform - CRA of the Federal Senate. For this purpose, we will use data: 1) political profile of committee members (party, number of mandates on the Senate and political office); 2) socio-demographic profile (region and gender); 3) seniority and expertise: professional performance (educational level, vocational training area, professional practice area). The data used are from 2005 to 2018, which includes the time of existence of the CRA, available on the Federal Senate website and in the Annual Report of the Presidency of the Federal Senate. Thus, it was possible to verify that the CRA has since its origin a presence of more than $50 \%$ of members of the governing coalition, reaching about $80 \%$ in the second mandate of the Dilma government, that is, it is noted that there is a sharing of power between coalition member parties and the ruling party in the CRA. Moreover, it was possible to infer that the presidency and vice-presidency were mostly taken by the ruling coalition parties and the ruling party, thus indicating little room for opposition articulation. There is also the party fragmentation verified in plenary reflected in the CRA whose number of parties ranged from 8 to 11; the members are in their first or second term, however, they are not "inexperienced" politicians, most of them have already occupied other elective positions, especially in the Legislature.

Keywords: Senate; Legislative Studies; Committee on Agriculture and Agrarian Reform.

\section{Introdução}

As bases institucionais do sistema político brasileiro são permeadas pelo presidencialismo de coalizão. Ou seja, o partido que ascende à Presidência da República, de posse da máquina do Executivo, busca construir bases de apoio dentro do parlamento, a fim de ampliar as chances de sucesso de sua agenda de governo, e isto acontece, em grande parte, através do uso da patronagem - distribuição de pastas ministeriais, cargos comissionados, emendas orçamentárias, por exemplo. Esta construção de alianças é centrada nos líderes partidários, pois eles detêm mecanismos que reforçam a disciplina dos parlamentares nas votações nominais em plenário, logo, isto lhes dá um poder de barganha frente ao Executivo, compelindo-o a entrar em negociação em prol da construção de consenso - inclusive, consenso sobre a agenda de política pública que irá ao Congresso Nacional -, em troca de votos. Portanto, o Executivo negocia as benesses (a patronagem) com os líderes partidários, que, em troca, "garantem" os votos necessários para a aprovação da agenda governamental de políticas públicas (SANTOS, 2003; POWER, 2015). 
Em contrapartida, os líderes partidários impõem, através de suas prerrogativas, que os parlamentares apresentem um comportamento disciplinado nas votações, ou seja, os líderes barram o comportamento individualista, oportunista e clientelista que podem apresentar os parlamentares - é do interesse do parlamentar manter uma conexão com sua base eleitoral, e isso só é possível se ele for capaz de trazer melhorias para o seu distrito eleitoral, a sua localidade. Como o parlamentar quer ter acesso às benesses de posse do Executivo, submete-se a seguir o líder partidário nas votações, com o propósito de aumentar as suas chances de acesso a tais recursos, pois é o líder partidário que determina como serão distribuídas as vantagens negociadas com o Executivo. Do outro lado, existe o Executivo que, além do uso da patronagem, dispõe de um poder de agenda: promulgação de medidas provisórias, solicitação de pedidos de urgência, poder de veto integral ou parcial, mecanismos que estimulam os parlamentares a deliberar acerca dos seus projetos de lei (FIGUEIREDO; LIMONGI, 2006; POWER, 2015).

Observa-se que existe uma agenda de estudos firmada sobre a relação do Legislativo e Executivo, visto que há interesse da comunidade científica sobre o desenho institucional que emerge após Constituinte-1988, ou seja, um sistema político marcado pelo presidencialismo de coalizão, associado ao multipartidarismo, federalismo, eleições proporcionais à Câmara dos Deputados, eleições majoritárias ao Senado Federal, e um forte bicameralismo (ABRANCHES, 1988). Por outro lado, percebe-se que existe uma falta de estudos quanto ao Senado Federal brasileiro, sobretudo no que tange às comissões permanentes. Isto acontece porque o Senado Federal assume frequentemente um posicionamento de casa revisora, ou seja, os projetos provenientes do Executivo são primeiramente apreciados na Câmara dos Deputados, e caso sejam aprovados com emendas, substitutivo ou aprovado na íntegra, segue para o Senado Federal. Logo, a literatura especializada tende a debruçar-se mais sobre o comportamento dos deputados federais (PARO, 2014; ARAÚJO, 2012; NEIVA, 2011).

A literatura reconhece o bicameralismo brasileiro como forte. Lijphart (2008) utiliza-se de duas dimensões para caracterizar esta força: a simetria e a incongruência. É dito simétrico porque as duas casas legislativas, Câmara dos Deputados e Senado Federal, gozam de prerrogativas semelhantes, de tal modo que uma casa apresenta plena capacidade de intervir na decisão da outra, refletindo a participação idêntica no processo decisório. "Incongruência" refere-se à forma diferenciada cujas casas legislativas são 
formadas na arena eleitoral, isto é, eleições proporcionais à Câmara dos Deputados e eleições majoritárias ao Senado Federal, diferenças inclusive no tamanho: são 513 deputados e 81 senadores. A lógica por trás deste sistema de seleção é captar a pluralidade de preferências percebidas da sociedade brasileira (ARAÚJO, 2012; RUBIATTI, 2017).

A razão de existência do Senado Federal é representar de forma igual os entes da federação (estados), pode se pensar, pois, que a atuação dos senadores se guiaria por interesses clientelistas, paroquiais, restritos ao território de origem. Contudo, o que se observa é um comportamento partidário, tal como verifica-se na Câmara dos Deputados. Os governadores pouco determinam o comportamento dos senadores, e os indicadores relacionados ao partido governista e ao partido membro da coalizão, são mais significativos para descrever o comportamento dos senadores em plenário, de acordo com Neiva e Soares (2013). Indo além, Araújo (2008) afirma que as iniciativas de proposições do Senado Federal são, em sua maioria, de âmbito nacional e não paroquiais.

O Senado Federal, como casa revisora, recebe proposições iniciadas pelo Executivo, pela Câmara dos Deputados, pelos Tribunais Superiores e outros atores políticos que dispõem da prerrogativa para isso - todas as proposições não iniciadas pelos senadores, começam seu trâmite na Câmara dos Deputados. Sendo assim, a Câmara Alta (Senado) apresenta uma propensão de retenção, ou seja, parte dos projetos que entram em tramitação na casa, terminam por ser arquivados pela força do regimento, rejeitados ou prejudicados. Por outro lado, ela não desponta como uma casa de obstrução, visto que pouco mais da metade dos projetos em trâmite retornam para a câmara de origem (RUBIATTI, 2017).

Portanto, o objetivo deste trabalho é contribuir para a agenda de estudos sobre o sistema de comissões do Senado Federal, realizando uma análise da composição sociopolítica da Comissão de Agricultura e Reforma Agrária (CRA) do Senado Federal. Para este fim, utilizaremos dados sobre: 1) perfil político dos membros da comissão (partido, número de mandatos no Senado); 2) perfil sociodemográfico (região e gênero); e 3) expertise (atuação profissional, ocupação em cargos políticos-eletivos, nível de escolaridade, área de formação profissional) e seniority. Os dados utilizados referem-se ao período de 2005 a 2018, o que engloba o tempo de existência da CRA, disponibilizados no site do Senado Federal, e nos Relatórios Anuais da Presidência do Senado Federal 
(BRASIL, 2015, 2016, 2017, 2018). A construção dos gráficos e tabelas foi realizada através da ferramenta Excel (Microsoft Office).

Nota-se que as comissões estão assumindo, progressivamente, um papel de destaque no processo legislativo. Pereira e Mueller (2000) afirmam que o Executivo busca construir lealdade em determinadas comissões, apesar de possuir a prerrogativa de solicitar pedido de urgência e, assim, abstrair a participação da comissão na tramitação legislativa. O Executivo se esforça para estabelecer apoio as suas proposições de políticas públicas no interior das comissões, atribuindo a estas, uma posição estratégica nas negociações entre o Executivo e o bloco parlamentar comandado pelo líder partidário. $\mathrm{O}$ interesse em estimular a lealdade das comissões é uma realidade, posto que o Executivo se esforça em poupar o seu capital político, e poupar do desgaste os partidos membros da sua aliança de coalizão, o que poderia ocorrer, caso a sua proposta de política pública fosse deliberada em plenário. Assim, procura evitar o confronto direto em plenário, além de impedir que reflexos negativos se formem ante a opinião pública.

Da outra forma, as comissões são vistas, erroneamente, como fracas e de pouca importância, isto porque, quando é feito pedido de urgência legislativa a um determinado projeto, que está sob deliberação na comissão, este segue imediata e diretamente à ordem do dia, ou seja, a comissão deixa de atuar no processo. Entretanto, o que se verifica, decerto, é que a solicitação do pedido de urgência é utilizado a fim de frear a ação individual dos parlamentares, e segundo Freitas (2016), ele só acontece quando o projeto de lei já passou por todo o processo ordinário de tramitação na comissão e, portanto, está pronto para a pauta.

É delegada às comissões, a prerrogativa de iniciar, rejeitar ou aprovar projetos de lei sem necessidade de deliberação do plenário - no caso do Senado Federal, esta competência é denominada de poder terminativo. São também prerrogativas das comissões: exercer o papel de fiscalização e controle dos planos e programas do governo; requerer pedidos de audiência pública a fim de ampliar as informações a respeito do projeto de lei que está sob deliberação na comissão, além de ser um espaço para a manifestação das minorias, aberto a diversos setores da sociedade organizada. Assim sendo, verifica-se que a comissão agiliza o processo legislativo, uma vez que 
descentraliza a tramitação e contribui para o aperfeiçoamento da estrutura do projeto de lei (LEMOS, 2008; AMARAL, 2011; SILVA, 2016).

Para Lemos (2008), quanto maior a quantidade de comissões, maior é a capacidade da casa legislativa em deliberar simultaneamente, sobre uma diversidade de proposições acerca dos mais variados temas - atualmente, o Senado Federal possui 14 comissões permanentes em funcionamento. Deste modo, conclui-se que quanto maior o número de comissões, mais institucionalizada e complexa é a casa legislativa, e mais pluralidade de preferências são representadas.

A proposta das comissões é representar um microcosmo de preferências observadas em plenário, ou seja, as comissões seriam o reflexo do espectro ideológico presente em plenário. Essa representação dos blocos parlamentares, pode facilitar a participação das minorias. Neste aspecto, favorece um refinamento do debate entre as opiniões divergentes sob a pluralidade de informações, com incentivos a construir consensos (LEMOS, 2008; ROCHA; BARBOSA, 2008).

Aguiar (2013) e Nascimento (2012), orientados pelos estudos dos sistemas de comissão norte-americano, afirmam que o sistema de comissão brasileiro pode ser explicado, sob o prisma da escolha racional, pelo modelo agente-principal, isto é, um principal - o plenário - delega prerrogativas a um agente, no caso, as comissões. Dessa forma, de acordo com esta interpretação, para a teoria distributivista, a comissão serviria aos propósitos dos parlamentares e a seu distrito eleitoral, ela seria para o parlamentar, um espaço de captação de recursos para sua base eleitoral: obtenção de ganhos em troca de votos. Para a perspectiva informacional, a comissão seria um espaço gerador de informações para o aprimoramento das políticas públicas em trâmite, pois é de interesse dos parlamentares e do Executivo que a política pública, a ser implementada, seja bem avaliada pela opinião pública. Seria um espaço para a especialização (expertise) do parlamentar, e quanto mais ele permanecer, em sucessivos mandatos, como membro de dada comissão (seniority), maior será o ganho em experiência, conhecimento e cargos de destaques. Por fim, para a teoria partidária, as comissões seriam um instrumento utilizado para impor as preferências e preservar os interesses dos partidos (PARO, 2014; LEMOS, 2008; ROCHA; BARBOSA, 2008; PEREIRA; MUELLER, 2000). 
Os líderes partidários, junto à mesa diretora, fazem as indicações para a composição das comissões. Para decidir qual parlamentar indicar, o líder considera a lealdade e expertise do parlamentar. Os líderes partidários procuram ter membros leais nas comissões, para facilitar a negociação de votos face à presidência da Comissão, em troca das benesses. Logo, o líder partidário avalia a disciplina partidária dos parlamentares, isto é, observa quais parlamentares comportam-se de forma disciplinada nas principais votações em plenário, e quais os que o seguem nas votações em plenário. Contrabalanceando a isso, o líder partidário avalia a expertise, que é a formação profissional/acadêmica do parlamentar, sua atividade econômica e sua atuação política quais cargos políticos o parlamentar já assumiu. O interesse pela expertise do parlamentar existe, dado que os líderes partidários se preocupam acerca da qualidade das políticas públicas em trâmite, a fim de dirimir as incertezas das proposições (MÜLLER, 2005; SANTOS, 2006; PEREIRA; MUELLER, 2003).

Ao presidente da comissão, cabe ditar o ritmo da tramitação; escolher os relatores e relatores-substitutos e distribuir-lhes as matérias; conceder a palavra aos membros da comissão e aos líderes partidários, caso solicitada; submeter à votação as questões alvo de deliberações, e oficializar o resultado da votação; resolver as questões de ordem ou reclamação; e definir e informar as pautas às lideranças partidárias e aos membros da comissão. É função da relatoria examinar o projeto de lei, sugerir alterações, caso perceba que seja necessário impetrar requerimentos de audiência pública, a fim de coletar mais informações e, adiante, submeter o seu parecer ao plenário da comissão para deliberação, que caso aprovado, será enviado ao Congresso Nacional (SILVA, 2016; AGUIAR, 2013).

Lemos (2008) apresentou indicadores de aprovação dos projetos oriundos das comissões do Senado Federal, da área da saúde e educação, entre 1988 e 1994. Do total de projetos dessa área, $4 \%$ eram provenientes de comissões, porém com $75 \%$ de taxa de aprovação, sendo que, em contrapartida, os projetos apresentados individualmente pelos parlamentares tiveram uma taxa de 6,49\% de aprovação. Ademais, não houve veto a nenhuma proposta oriunda das comissões, ao passo que $22,64 \%$ das propostas individuais foram, parcialmente ou totalmente, vetadas pela presidência da República.

Em suma, nesta seção, mostrou-se a relevância que as comissões apresentam no processo legislativo, como um lócus de poder, cujos atores políticos são impulsionados a 
negociar para que seja aprovada uma agenda política pública que represente, tanto as políticas defendidas pela presidência da República quanto aquelas priorizadas pelos blocos parlamentares integrantes da coalizão governista. São espaço onde ocorre o compartilhamento de poder, oportunizando a atuação mais incisiva da oposição, das minorias, possibilitando a manifestação dos interesses de setores organizados da sociedade, de lobbys, além de ser um espaço gerador informacional e de desenvolvimento da expertise.

\section{Resultados}

Nessa seção, serão apresentados os resultados do levantamento de dados sobre a composição da Comissão de Agricultura e Reforma Agrária. Para tanto. Estão divididos em: i) aspectos partidários e de coalizão: serão apresentadas as informações sobre os partidos aos quais pertencem os senadores, identificando os que participaram da coalizão com o governo; ii) aspectos de seniority e expertise: serão apresentadas as informações sobre a seniority (antiguidade do senador na CRA), a frequência com que os partidos assumiram a presidência e a vice-presidência na CRA, a escolaridade, a experiência profissional dos senadores, a atuação política prévia e o número e frequência de mandatos assumidos no Senado; e iii) aspectos regionais e gênero: informações sobre os estados representados pelos membros da CRA, e distribuição por gênero. Ressalta-se que estes dados se referem aos membros titulares que atuaram na CRA durante todo o intervalo estudado (2005 a 2018), englobando a $52^{\mathrm{a}}, 53^{\mathrm{a}}, 54^{\mathrm{a}}$ e $55^{\mathrm{a}}$ legislaturas.

Para a realização dessa análise, os dados sobre a composição da CRA foram coletados, por ano, nos Relatórios Anuais da Presidência do Senado (RAP). Desta forma, todo senador que ocupou uma cadeira como titular na comissão foi computado. Ainda dos RAPs, buscou-se as informações sobre os partidos e estados a que pertenciam os titulares da CRA. Após essa primeira coleta, foram buscadas no site do Senado, as informações sobre a escolaridade, área de atuação profissional, número de mandatos no Senado e outros mandatos eletivos que os senadores tiveram. As informações sobre os 
partidos que participaram da coalizão governista, e que ocuparam cadeira na CRA, foram cedidas pelo Centro Brasileiro de Análise e Planejamento - CEBRAP. ${ }^{1}$

Cabe destacar que a CRA é formada por 17 membros titulares (e 17 suplentes). Porém, como preferiu-se trabalhar com todos os membros que ocuparam cadeiras na comissão no período, esse número é bem maior, visto que, em um único ano, não foram apenas 17 membros. No decorrer do processo legislativo, há substituições de membros titulares, trocas de vagas negociadas entre partidos ou bancadas, seguindo os interesses do partido e determinações dos líderes partidários. Portanto, apesar do mandato na comissão ser de 2 anos, muitos senadores ocupam por menos tempo o cargo de titular na CRA. Outrossim, optou-se por escolher a CRA como um elemento amostral do sistema de comissões do Senado Federal, em virtude de sua longevidade (14 anos de legislaturas completas) e a relevância dos temas nela tratados.

\subsection{Aspectos partidários de coalizão}

A tabela 1 apresenta a distribuição partidária dos titulares que compuseram a CRA nas sucessivas legislaturas. Nota-se o crescente interesse dos partidos em participar da Comissão ao longo das legislaturas: na $52^{\mathrm{a}}$, foram 8 partidos, na $54^{\circ}$ já foram 11 , e na seguinte, 10 partidos. Estes dados indicam a importância que a CRA recebe durante sua trajetória de duração no processo legislativo. Além disso, observa-se que a composição das comissões segue, na medida do possível, a fragmentação partidária do plenário, como já dito por Abranches (1988), Figueiredo e Limongi (2007), entre outros. Isto é, há uma relação entre o crescente número de partidos no Senado Federal e a fragmentação partidária verificada na CRA. Na 52 ${ }^{\text {a }}$ legislatura, 11 partidos obtiveram cadeiras no Senado Federal, seguindo-se por 15,18 e 22 , nas legislaturas $53^{\mathrm{a}}$, $54^{\mathrm{a}}$ e $55^{\mathrm{a}}$, respectivamente. Contudo, o impeachment da ex-presidente Dilma Rousseff, na legislatura $55^{\mathrm{a}}$, pode ter influenciado a retirada do PTB e PSC da Comissão, ao passo que pode ter influenciado o ingresso do PPS durante o governo de Michel Temer.

\footnotetext{
${ }^{1}$ Teve-se acesso às informações, a partir da "base de dados-Cebrap", cedidas extraoficialmente, na forma de tabelas (Excel). Sobre o conjunto desses dados, não existe, a princípio, nenhuma publicação oficial.
} 
FERREIRA, Wesley R. S. Perfil sociopolítico dos membros titulares da comissão da agricultura e reforma agrária do senado federal. Caos - Revista Eletrônica de Ciências Sociais, João Pessoa, n. 23, p. 113 - 138, jul./dez. 2019. Disponível em: https://periodicos.ufpb.br/ojs2/index.php/caos/index.

Dentre os partidos que ocuparam cadeiras de titular na CRA, cabe destaque ao PFL/DEM, que perde significativamente espaço na CRA, variando de $27,3 \%$ para $3,4 \%$ da $52^{\mathrm{a}}$ para $55^{\mathrm{a}}$ legislatura. O mesmo fato se verifica com o PSDB, variando de $18,2 \%$ para 6,9\% no mesmo intervalo das legislaturas. O PMDB se manteve constante, 18,2\% a $20,7 \%$, embora tenha havido um esvaziamento de ocupação na legislatura $54^{\mathrm{a}}$, quando se registrou 11,4\% de participação. Verifica-se o crescimento do PT, variando de 13,6\% para $17,2 \%$, da $52^{\mathrm{a}}$ para a $55^{\mathrm{a}}$ legislatura. Cresce também a participação do PDT, de $4,5 \%$ para $13,8 \%$, da $52^{\mathrm{a}}$ para a $55^{\mathrm{a}}$ legislatura.

Tabela 1: Distribuição partidária dos titulares da CRA por legislatura

\begin{tabular}{ccccc}
\hline Partidos/Legislaturas & $\mathbf{5 2}^{\mathbf{a}}$ & $\mathbf{5 3}^{\mathbf{a}}$ & $\mathbf{5 4}^{\mathbf{a}}$ & $\mathbf{5 5}^{\mathbf{a}}$ \\
\hline PSDB & $18,2 \%$ & $21,9 \%$ & $20,0 \%$ & $6,9 \%$ \\
\hline PFL/DEM & $27,3 \%$ & $21,9 \%$ & $2,9 \%$ & $3,4 \%$ \\
\hline PMDB & $18,2 \%$ & $18,8 \%$ & $11,4 \%$ & $20,7 \%$ \\
\hline PT & $13,6 \%$ & $15,6 \%$ & $11,4 \%$ & $17,2 \%$ \\
\hline PL/PR & $9,1 \%$ & $6,3 \%$ & $20,0 \%$ & $10,3 \%$ \\
\hline PSB & $4,5 \%$ & $3,1 \%$ & $5,7 \%$ & $6,9 \%$ \\
\hline PDT & $4,5 \%$ & $6,3 \%$ & $8,6 \%$ & $13,8 \%$ \\
\hline PTB & & $6,3 \%$ & $5,7 \%$ & \\
\hline PSC & & & $2,9 \%$ & \\
\hline PP & & & $8,6 \%$ & $10,3 \%$ \\
\hline PSD & & & & \\
\hline PPS & & & & $3,9 \%$ \\
\hline PC do B & $4,5 \%$ & & \\
\hline Total & $100,0 \%$ & $100,0 \%$ & $100,0 \%$ & $100,0 \%$ \\
\hline
\end{tabular}

Fonte: Elaboração própria a partir dos Relatórios Anuais da Presidência do Senado Federal entre 2005 e 2018

No gráfico1, estão representadas as informações sobre a participação dos partidos da coalizão governista e do partido do governo na CRA. O que se percebe, de forma geral, é a marcante participação dos partidos da coalizão governista, sempre acima de 50,0\%, havendo momento em que o percentual chegou a 80,0\% (em 2015). Por outro lado, o partido governista demonstra-se pouco interessado em participar da CRA, isto é, durante os governos petistas, a taxa de participação atingiu, no máximo, 19,0\%. Todavia, após o impeachment da ex-presidente Dilma Rousseff (PT), e a ascensão do ex-presidente Michel Temer (PMDB), há uma ampliação do partido governista na CRA, chegando a 25,0 \% em 2017 e 2018. Ademais, nota-se o esvaziamento da base governista, refletido na CRA entre os anos de 2015 a 2016, o que pode estar relacionado aos desdobramentos 
do processo do impeachment há pouco mencionado, variando de 80,0\% em 2015, para $52,6 \%$ em 2016.

Os dados (tabela 1 e gráfico 1) indicam que os governos petistas construíram uma base heterogênea, congregando apoio de partidos com vieses ideológicos distintos, como o PMDB, PP e PL/PR, mais à direita, ao passo que o PCdoB, PSB, PDT são partidos vistos mais à esquerda, juntamente com o próprio PT, como indicam Limongi e Figueiredo (2017). Estes dados indicam que o objetivo dos governos foi criar e manter uma ampla base de apoio, com propósito de aumentar as chances de sucesso da sua agenda de políticas públicas, ou seja, o interesse de construir alianças, supera as diferenças ideológicas. Entretanto, como apontado por Bertholini e Pereira (2017), bases heterogêneas são instáveis, pois nelas se instaura um conflito político-partidário, isto é, partidos de concepções diversas dificultam o trabalho de coordenação do governo, posto que colocam demandas que discordam entre si, criando uma situação de disputa, que divide aliados em busca da atenção e benesses do governo. De resto, o que se verifica, pelo gráfico 1, decerto, que existe um compartilhamento de poder, isto é, o partido governista cede espaços de decisão, cujos temas são de interesse dos partidos membros da coalizão; em troca, estes partidos atuam de forma favorável e/ou de forma menos obstrutivas às proposições da presidência/partido governista.

Gráfico 1 - Participação do governo na composição da CRA: partido do governo e coalizão do governo

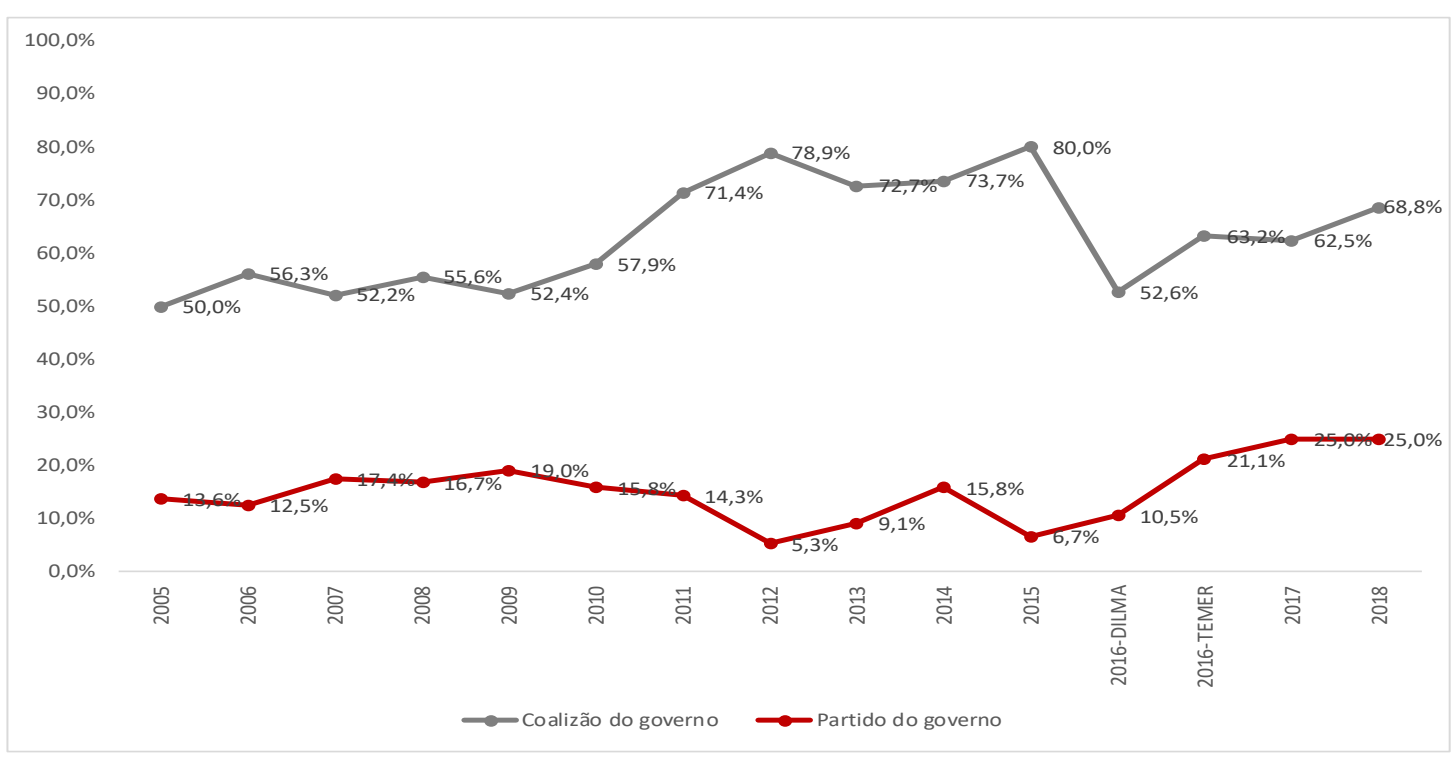

Fonte: Elaboração própria a partir das informações cedidas pelo Centro Brasileiro de Análise e Planejamento - CEBRAP 


\subsection{Aspectos de seniority e expertise}

Nesta seção, serão debatidas as informações de seniority e expertise. O primeiro diz respeito à quantidade de tempo em que o senador permaneceu na CRA. Quanto maior este tempo, mais ele pode desenvolver a expertise, ou seja, ampliar o conhecimento sobre os temas tratados na CRA, além de aumentar a recorrência de assumir funções importantes, tal como a relatoria, presidência e vice-presidência. O segundo, no contexto aqui tratado, diz respeito à experiência profissional previa do senador, a escolaridade e os cargos políticos já assumidos.

Gráfico 2 - Permanência dos senadores, por ano, na CRA entre 2005 e 2018

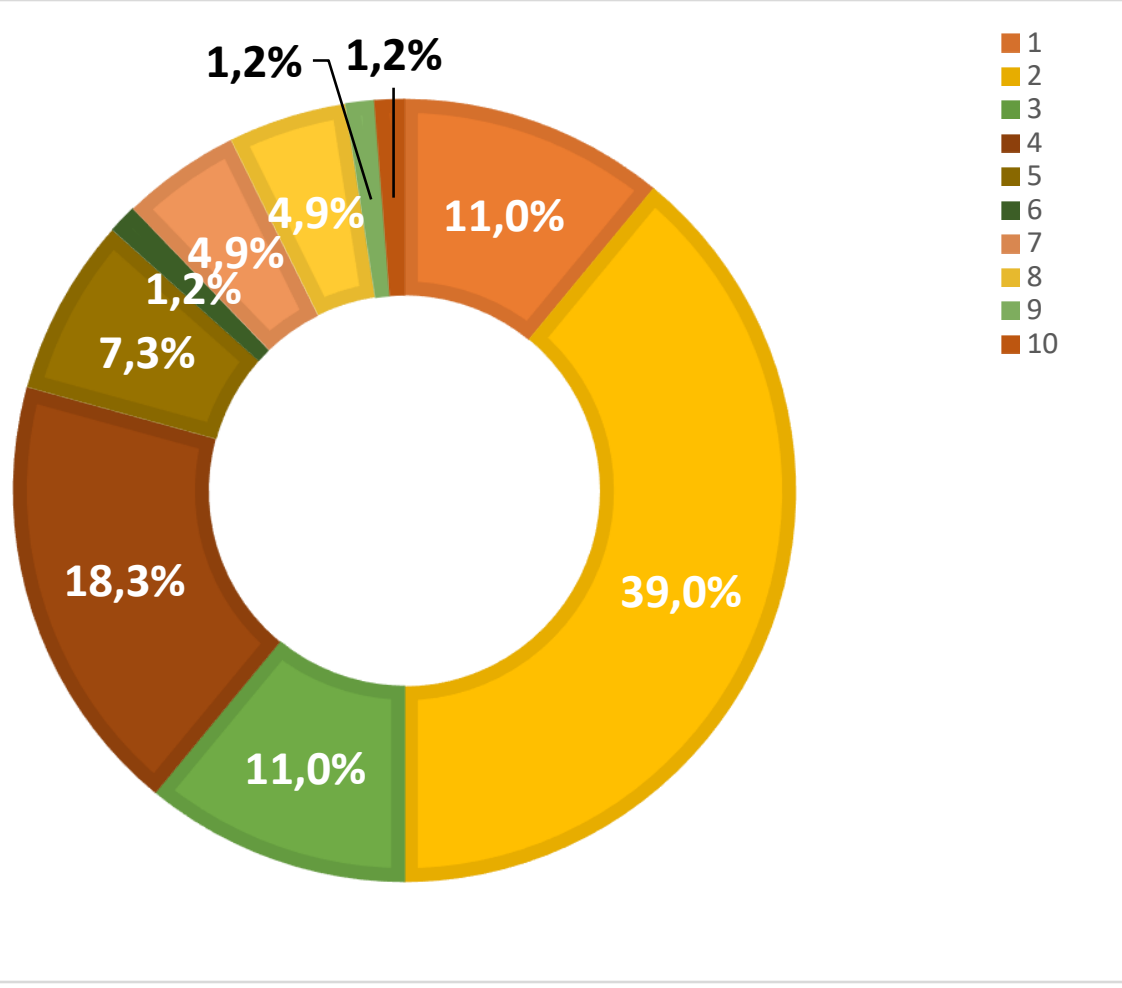

Fonte: Elaboração própria a partir dos Relatórios Anuais da Presidência do Senado Federal

O gráfico 2 demonstra que 39,0\% dos senadores que ingressaram na CRA, nela permaneceram por pelo menos 2 anos. Vale ressaltar, que os anos aqui computados não são, necessariamente, anos consecutivos, ou seja, por vezes o senador sai da CRA e posteriormente regressa à Comissão. Isto ocorre em virtude de a indicação, para ingressar na CRA, ser feita pelo líder partidário, logo, a vaga que o partido tem direito, é utilizada de acordo com os interesses partidários, e não de acordo com interesses particularistas do parlamentar. Portanto, o que se pode afirmar é que não está havendo o desenvolvimento 
de expertise na CRA, visto que, pelo menos cerca de 60,0\% das permanências, não ultrapassam 3 anos (pouco mais de 2 anos, tempo de permanência regimentalmente obrigatório). Por outro lado, poucos $(4,9 \%)$ ficaram um mandato inteiro (oito anos), menos ainda os que passaram nove anos $(1,2 \%)$ e dez anos $(1,2 \%)$. O senador Delcídio do Amaral (PT) foi o único que teve permanência de dez anos na CRA. Então, de acordo com as perspectivas apresentadas por Aguiar (2013) e Nascimento (2012), o viés partidário demonstra-se mais determinante para analisar a CRA, em detrimento aos viés distributivista e o informacional.

Gráfico 3 - Presidências assumidas na CRA por partido entre os anos 2005 a 2018

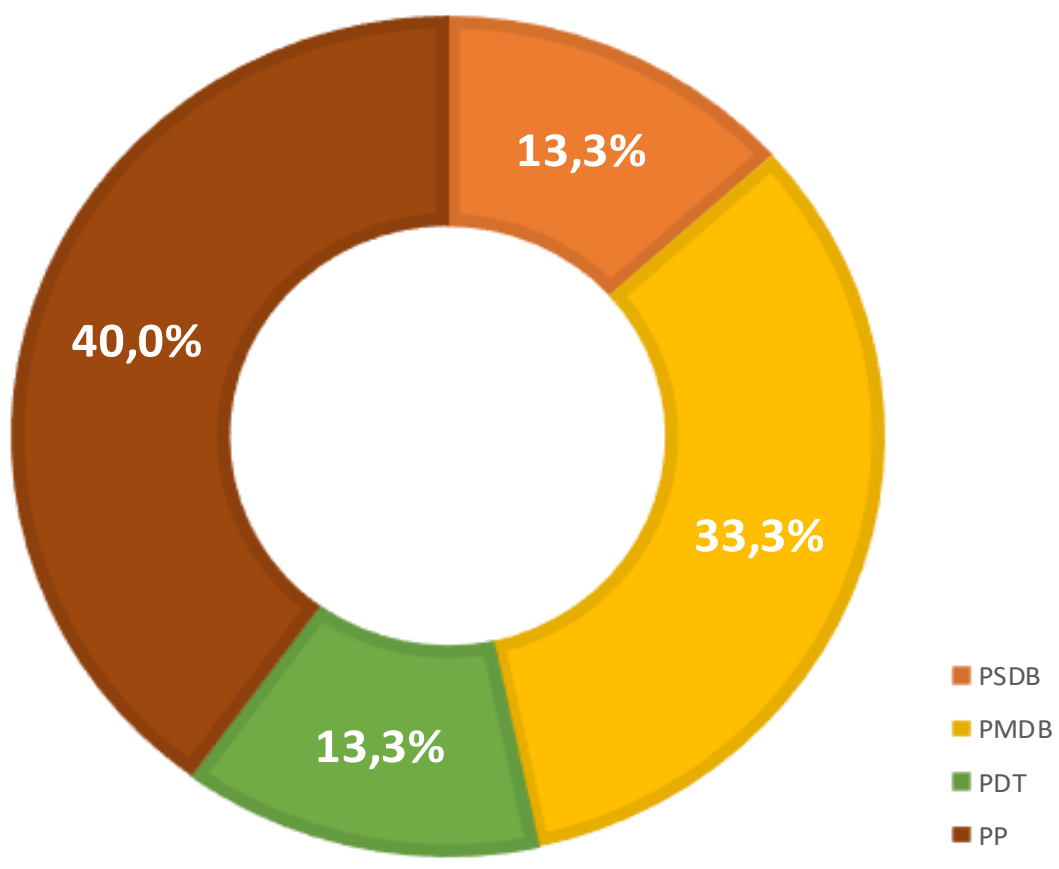

Fonte: Elaboração própria a partir dos Relatórios Anuais da Presidência do Senado Federal

No gráfico 3, estão ilustradas as informações acerca da quantidade de vezes que um determinando partido assumiu a presidência da CRA. Verifica-se que o PP assumiu 40,0\% das vezes, seguido pelo PMDB com 33,3\%. Indo além, de acordo com as informações do CEBRAP, o PP participou da coalizão governista entre 2005 a 2018, seguido pelo PMDB em igual período. O PDT participou da coalizão governista desde 2007 até o impeachment da ex-presidente Dilma Rousseff. Estas informações mostram 
que, apesar de o PT nunca ter assumido a presidência da CRA, os partidos membros da sua coalizão a assumiram. Fato que se repetiu no governo de Michel Temer, quando o cargo foi ocupado pelo senador Ivo Cassol, entre 2017 e 2018, integrante do PP, que então integrava a coalizão do novo governo.

Gráfico 4 - Vice-presidência assumida na CRA (por partido) entre os anos 2005 e 2018

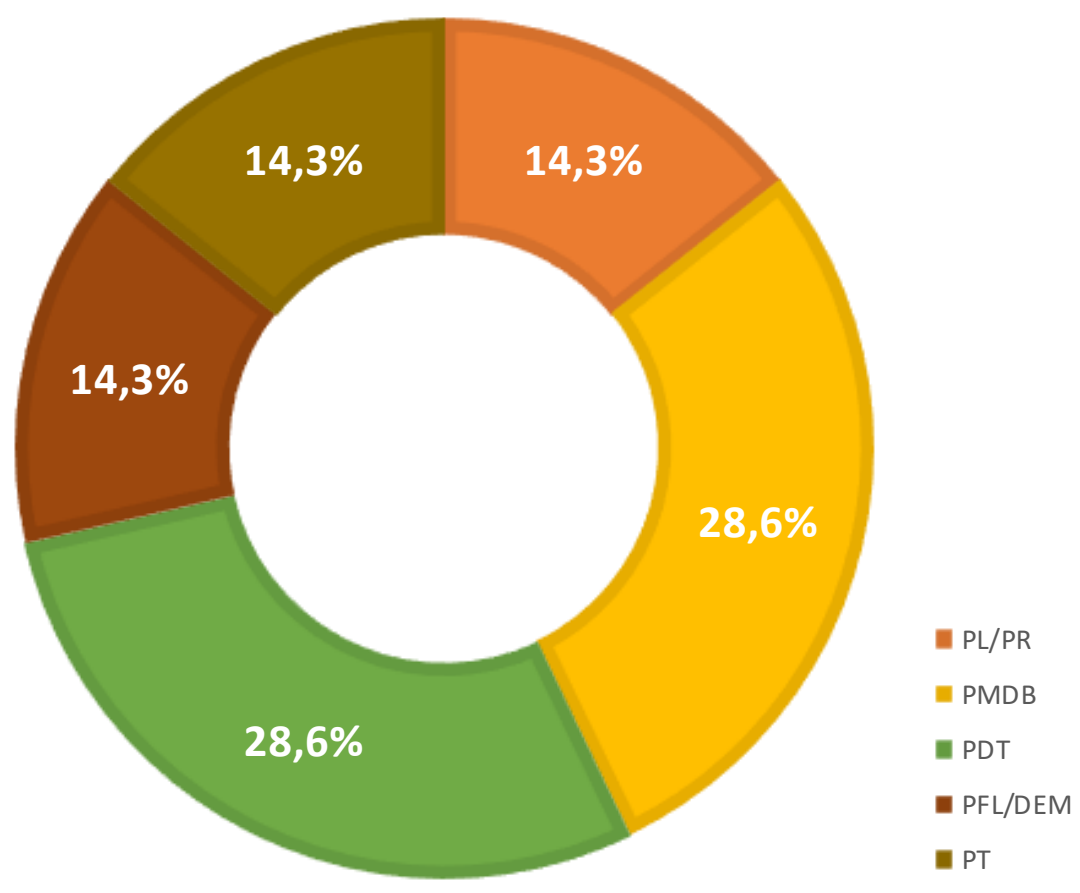

Fonte: Elaboração própria a partir dos Relatórios Anuais da Presidência do Senado Federal

No gráfico 4, estão ilustradas as informações acerca da quantidade de vezes que um partido assumiu a vice-presidência na CRA. Destaca-se que o PMDB e o PDT assumiram a vice-presidência da CRA, por 4 vezes cada um. Por outro lado, nota-se que o PT ocupou o cargo duas vezes (14,3\%), diferenciando-se em relação à presidência que não foi ocupada nenhuma vez. Como já mencionado no gráfico anterior, PMDB e PDT participaram da coalizão governista, sendo que o PMDB assumiu a vice-presidência nos anos de 2017 e 2018, com o senador Valdir Raupp. Portando, tal como ocorreu na presidência, a vice-presidência sempre foi ocupada por algum partido membro da coalizão governista. 
O gráfico 5 apresenta a escolaridade dos senadores. No início de funcionamento da $52^{\mathrm{a}}$ legislatura, $95,5 \%$ dos senadores possuíam ensino superior. $\mathrm{Na} 53^{\mathrm{a}}$, aparecem senadores apenas com o nível técnico/tecnológico e ensino médio, somando 15,7\%, contra os 78,1\% com ensino superior. Na legislatura seguinte $\left(54^{\mathrm{a}}\right), 40,0 \%$ não declararam qualquer formação escolar - o que torna a análise menos satisfatória -, e 54,3\% declararam possuir nível superior. Na última legislatura $\left(55^{\mathrm{a}}\right), 75,9 \%$ dos senadores apresentaram nível superior, e 20,7\% não declararam a escolaridade. De forma geral, os dados apontam que os senadores que ingressaram na CRA, em sua maioria, possuíam nível superior de escolaridade.

Gráfico 5 - Escolaridade dos membros titulares na CRA entre 2005 a 2018

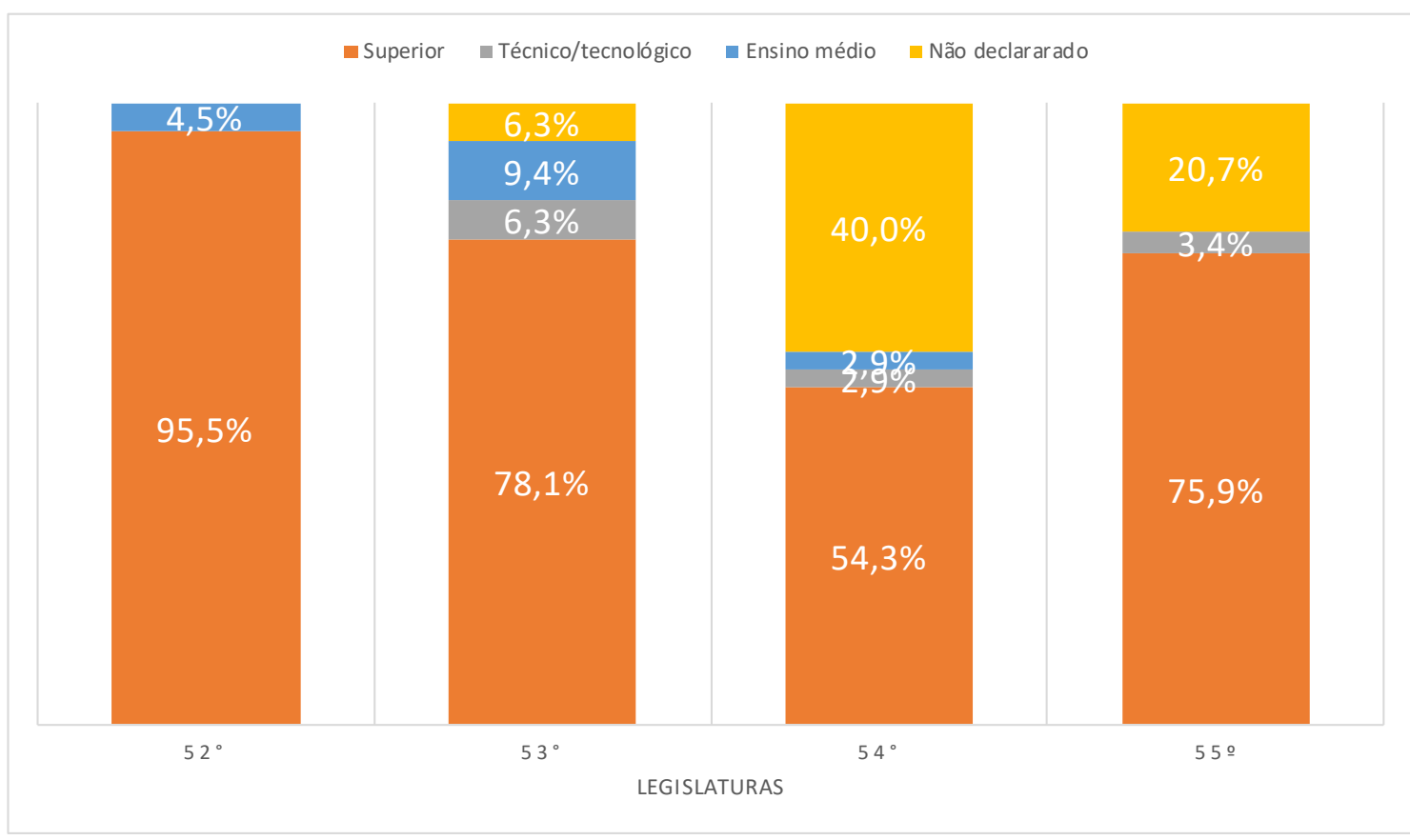

Fonte: Elaboração própria a partir das informações biográficas declaradas pelos senadores no site do Senado Federal

O gráfico 6 apresenta as profissões declaradas pelos senadores. Elas foram assim organizadas: primeira (p1), segunda (p2) e terceira (p3), conforme registrado na biografia dos senadores no site do Senado Federal. Nota-se que as profissões são diversas, contudo, uma parcela significativa se declara advogado, professor ou ambos. Além disso, senadores com profissões relacionados ao agronegócio também compuseram a CRA, de um lado, os agricultores, agropecuaristas, pecuaristas (empregadores), do outro, engenheiros agrônomos, engenheiros e médicos veterinários (empregados), podendo, em 
alguns casos, o senador exercer ocupações de ambos os lados. Além disso, há senadores relacionados à atividade econômica, como empresários, administradores, economistas e industriais. De resto, 16 senadores não declararam quaisquer profissões.

Gráfico 6 - Profissões dos membros titulares da CRA

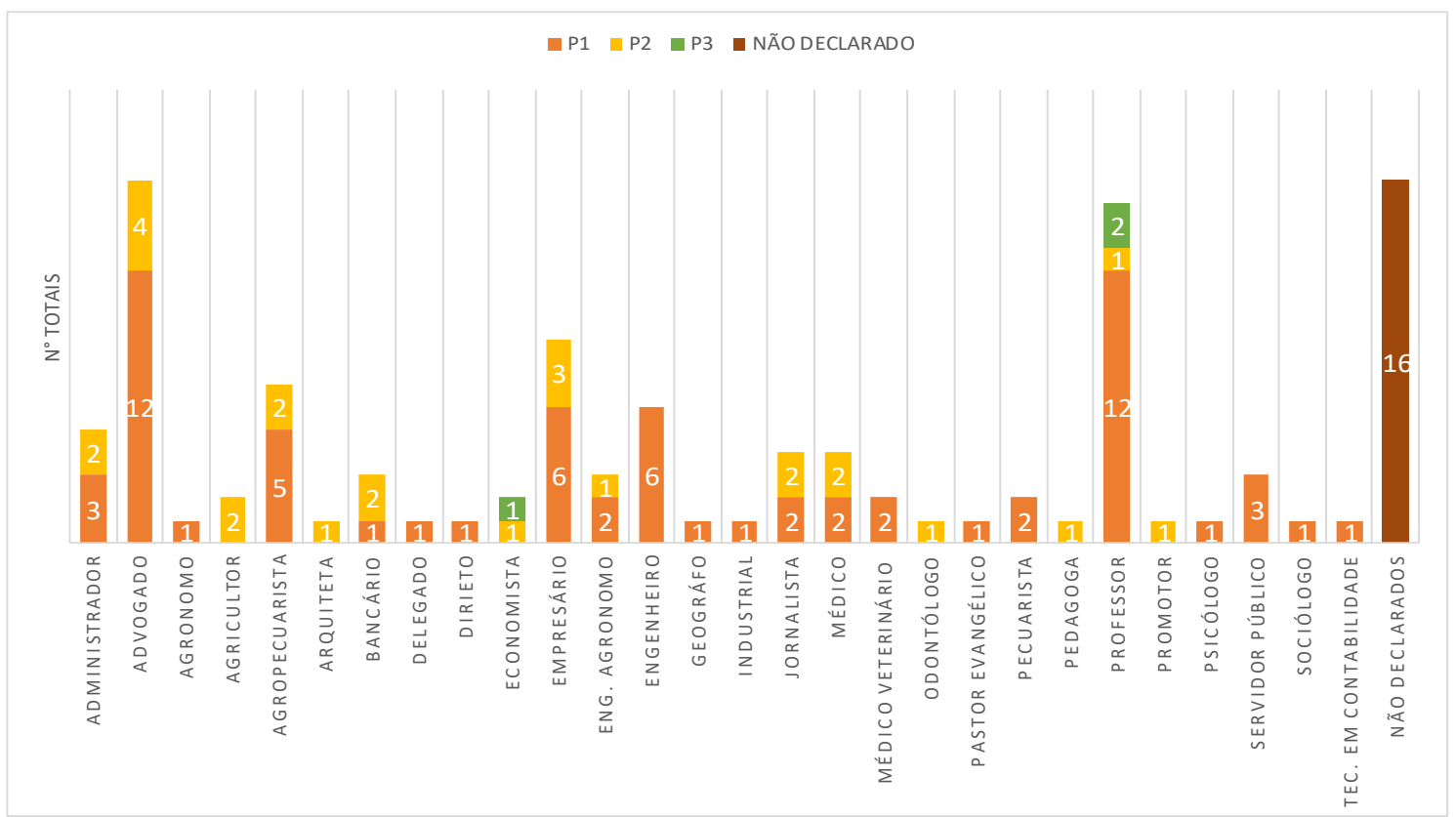

Fonte: Elaboração própria a partir da biografia declarada pelos senadores no site do Senado Federal

$\mathrm{Na}$ tabela 2, estão ilustradas as mesmas informações apresentadas no gráfico 6, porém organizados em categorias, sendo que, no caso dos senadores que declararam mais de uma profissão, foi selecionada a profissão de maior relevância para o presente estudo. Tal como ficou evidenciado no gráfico 6, a tabela 2 indica a participação considerável de professores e advogados, com a taxa variando entre 8,6\% a 18,2\% para os primeiros, e de 9,4\% a 22,7\% para os segundos. Destaque para Agropecuaristas/agricultores/pecuaristas, cuja taxa varia de 8,6\% a 17,2\%, e Engenheiros Agrônomos/Engenheiros/Médicos Veterinários, com variação entre $8,6 \%$ a 22,7\%. Por fim, Empresários/Industriais variaram de $4,5 \%$ a $17,2 \%$, e Administradores/Economistas ficaram em torno de $2,9 \%$ a $6,3 \%$. 
FERREIRA, Wesley R. S. Perfil sociopolítico dos membros titulares da comissão da agricultura e reforma agrária do senado federal. Caos - Revista Eletrônica de Ciências Sociais, João Pessoa, n. 23, p. 113 - 138, jul./dez. 2019. Disponível em: https://periodicos.ufpb.br/ojs2/index.php/caos/index.

Tabela 2 - Área de atuação dos membros titulares da CRA

\begin{tabular}{ccccc}
\hline Profissão/Legislaturas & $\mathbf{5 2}^{\mathbf{a}}$ & $\mathbf{5 3}^{\mathbf{a}}$ & $\mathbf{5 4}^{\mathbf{a}}$ & $\mathbf{5 5}^{\mathbf{a}}$ \\
\hline $\begin{array}{c}\text { Agropecuaristas/agricultores/pecuaristas } \\
\begin{array}{c}\text { Eng. Agrônomos/Engenheiros/Médicos } \\
\text { Veterinários }\end{array}\end{array}$ & $13,6 \%$ & $15,6 \%$ & $8,6 \%$ & $17,2 \%$ \\
\hline $\begin{array}{c}\text { Empresários/Industriais } \\
\text { Administrador/Economista }\end{array}$ & $4,5 \%$ & $18,8 \%$ & $8,6 \%$ & $10,3 \%$ \\
\hline Advogados & $4,5 \%$ & $9,4 \%$ & $5,7 \%$ & $17,2 \%$ \\
\hline Professores & $22,7 \%$ & $9,4 \%$ & $14,3 \%$ & $17,2 \%$ \\
\hline Outros & $18,2 \%$ & $12,5 \%$ & $8,6 \%$ & $17,2 \%$ \\
\hline Não declarados & $13,6 \%$ & $15,6 \%$ & $11,4 \%$ & $3,4 \%$ \\
\hline Total & & $12,5 \%$ & $40,0 \%$ & $17,2 \%$ \\
\hline
\end{tabular}

Fonte: Elaboração própria a partir da biografia declarada pelos senadores no site do Senado Federal

O gráfico 8 apresenta a experiência prévia dos membros titulares da CRA em outros cargos políticos, antes de serem eleitos a senadores e ingressarem na Comissão.

Gráfico 8 - Experiência prévia dos membros titulares da comissão em outros cargos eletivo na CRA entre 2005 a 2018

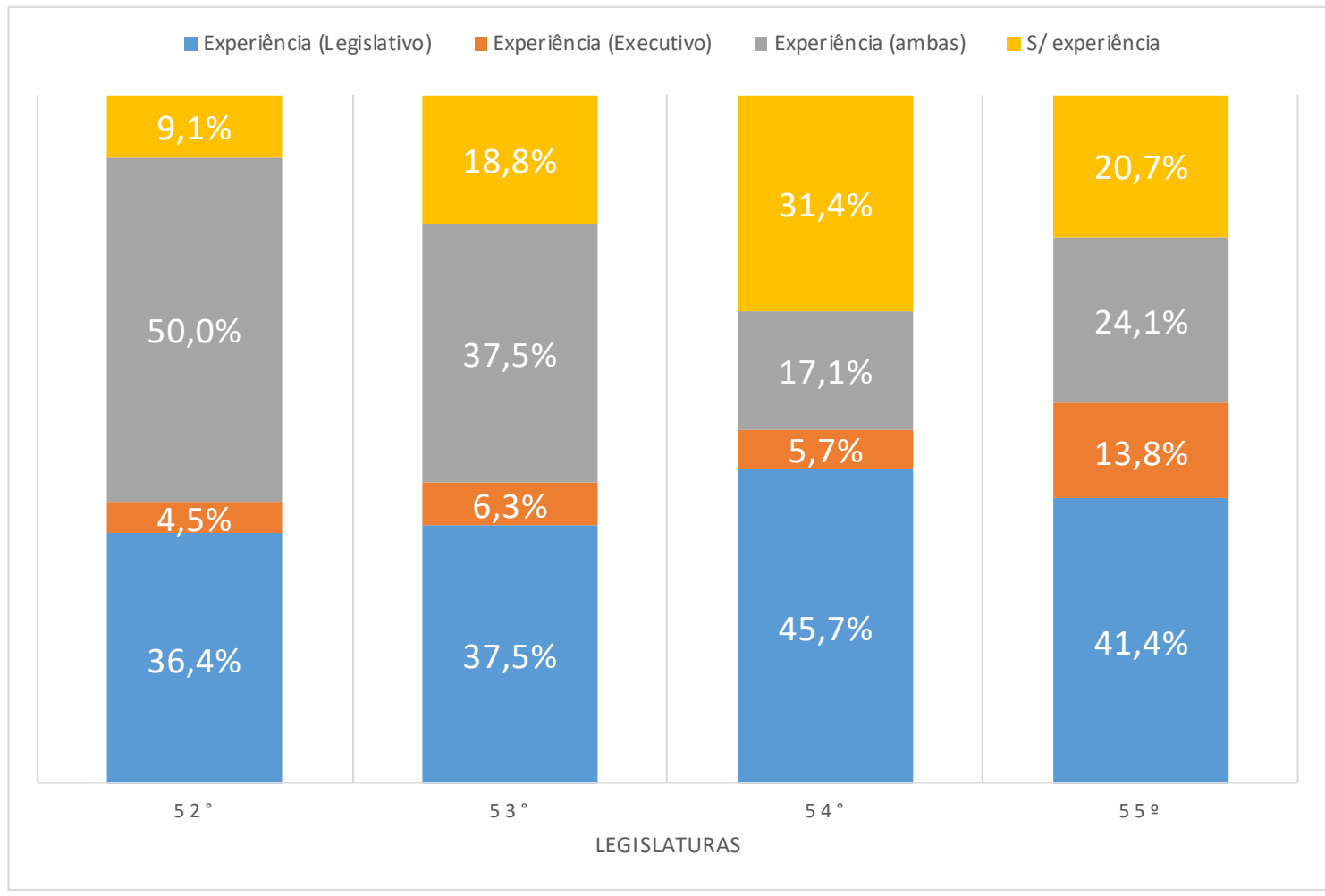

Fonte: Elaboração própria a partir da biografia declarada pelos senadores no site do Senado Federal 
Percebe-se que no início do funcionamento da CRA, 50,0\% dos senadores já tinham exercido cargos políticos, tanto na esfera do Legislativo quanto no Executivo, seja no âmbito municipal, estadual ou federal. Nas legislaturas seguintes $\left(53^{\mathrm{a}}\right.$ e $\left.54^{\mathrm{a}}\right)$, ocorre uma diminuição na quantidade de senadores que exerceram cargos políticos em ambas as esferas, cerca de $37,5 \%$ e $17,1 \%$, respectivamente; na $55^{a}$ legislatura amplia-se para 24,1\%. Os que exerceram cargos político apenas no Legislativo, destaque para 45,7\% na $54^{\mathrm{a}}$ legislatura. Os que exerceram apenas no Executivo, destaque para $13,8 \%$ na $55^{\mathrm{a}}$ legislatura. De forma geral, a quantidade de senadores que exerceram atividade política no Legislativo é superior à quantidade de senadores que exerceram atividade política exclusivamente no Executivo. De resto, em torno de $9,1 \%$ (legislatura $52^{a}$ ) a $31,4 \%$ (legislatura 54 ) não declararam qualquer experiência em cargos políticos.

Gráfico 9 - Quantidade de mandatos assumidos pelos membros titulares na CRA entre 2005 a 2018

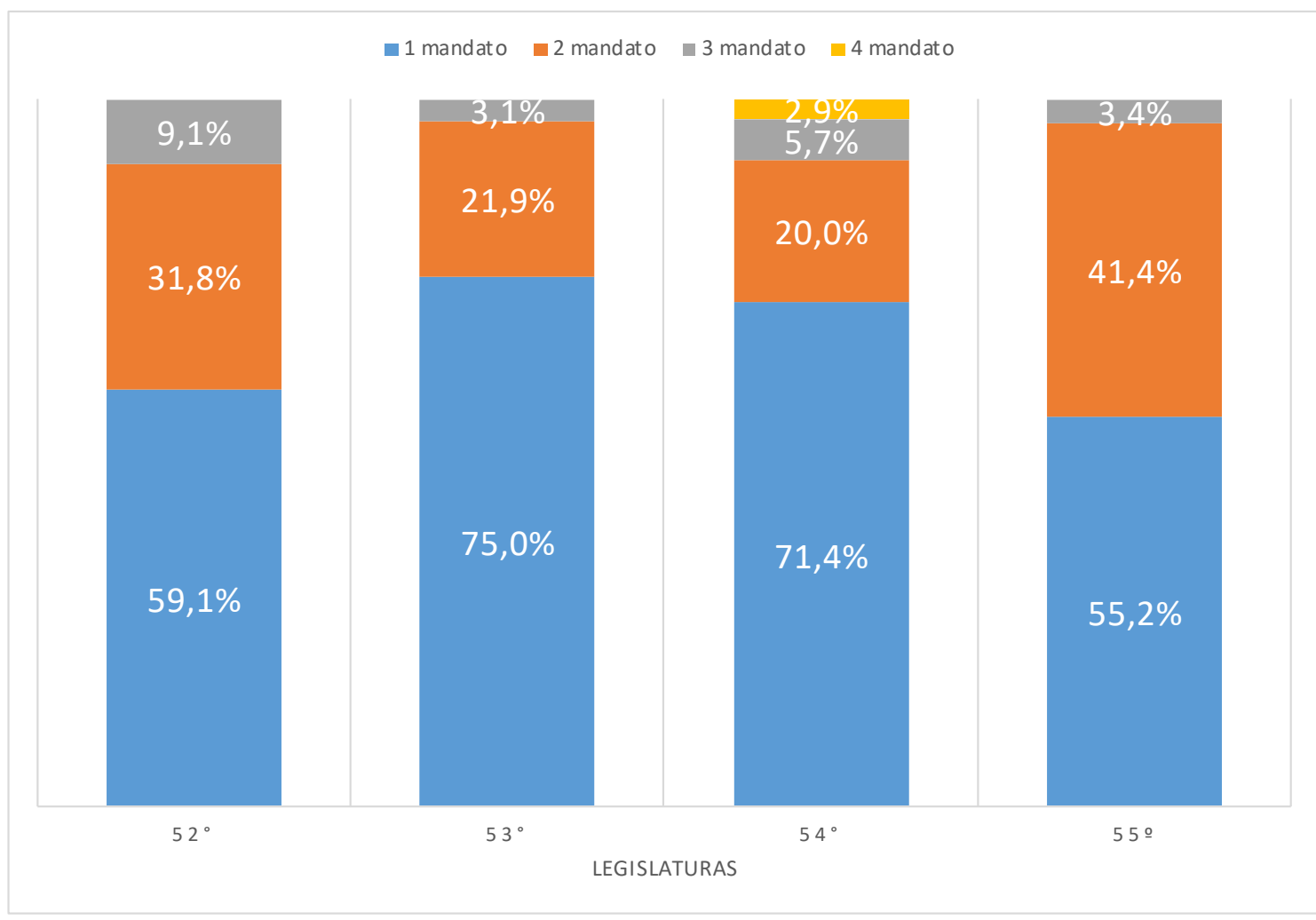

Fonte: Elaboração própria a partir da biografia declarada pelos senadores no site do Senado Federal

O gráfico 9 ilustra a quantidade de vezes em que os membros da CRA assumiram o cargo de senador. Nota-se que, em sua maioria, os senadores membros titulares

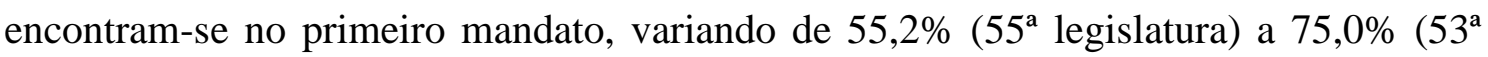


legislatura); por outro lado, a taxa de senadores no segundo mandato varia de $20,0 \%\left(54^{\mathrm{a}}\right.$ legislatura) a 41,4\% (55 legislatura). Houve apenas uma caso em que um senador (Casildo Maldaner do PMDB) se encontrava no quarto mandato, representando 2,9\%, na $54^{\mathrm{a}}$ legislatura.

\subsection{Aspectos regionais}

No gráfico 10, pode-se verificar a distribuição regional da composição dos membros titulares da CRA. Centro-oeste destaca-se por ocupar a maior quantidade de vagas, variando entre $27,3 \%$ (52 ${ }^{\mathrm{a}}$ legislatura) e $34,3 \%$ (54 ${ }^{\mathrm{a}}$ legislatura). Os dados indicam o esforço dos senadores do Centro-oeste em participar da CRA, o que causa estranhamento, haja vista que a região dispõe de uma quantidade menor de senadores na Câmara Alta, em comparação ao Norte e Nordeste, por exemplo. Afinal, por que o interesse dessa região em ocupar a CRA?

A especulação do agronegócio coloca o Centro-oeste como uma fronteira agrícola promissora, isto pode ter influenciado o esforço dos senadores a buscarem vagas na Comissão. Trazendo algumas informações a fim de ilustrar esta ideia, de acordo com Lourenzani e colaboradores (2016), a região Centro-oeste tornou-se a segunda maior produtora da cana-de-açúcar no Brasil, destacando-se os estados de Goiás e do Mato Grosso do Sul, cujo crescimento da produção em toneladas, deu-se às taxas de $437 \%$ e $369 \%$ entre 2003 e 2013, respectivamente. Somado a isso, e coincidindo com as informações do Filho (2016), em seu “Texto para Discussão", publicado pelo Instituto de Pesquisa Econômica Aplicada, no qual reporta uma expansão da fronteira agrícola no Centro-oeste nas duas últimas décadas, não só houve aumento da produção da cana-deaçúcar, como também ocorreu uma expansão da produção de soja e milho, da região Sul para o Centro-oeste. Decerto, os dados (gráfico 10) mostram a diminuição da participação dos senadores do Sul na CRA, da legislatura $52^{\mathrm{a}}$ para a $54^{\mathrm{a}}$, diminuição também observada dos senadores nordestinos entre essas duas legislaturas.

Observou-se também a composição de gênero na CRA. De acordo com Busanello e Rehbein (2017), gênero é uma categoria de análise empregada para avaliar a assimetria que existe entre homens e mulheres. Ela expressa as desigualdades sociais, mostrando como é produzida a estrutura hierárquica que alimenta as relações de poder entre homens e mulheres. Gênero é um conceito que reflete as relações sociais fundamentadas nas 
diferenças percebidas entre homens e mulheres, ou seja, o gênero é uma produção da cultura.

Gráfico 10 - Distribuição regional dos membros titulares na CRA entre 2005 a 2018

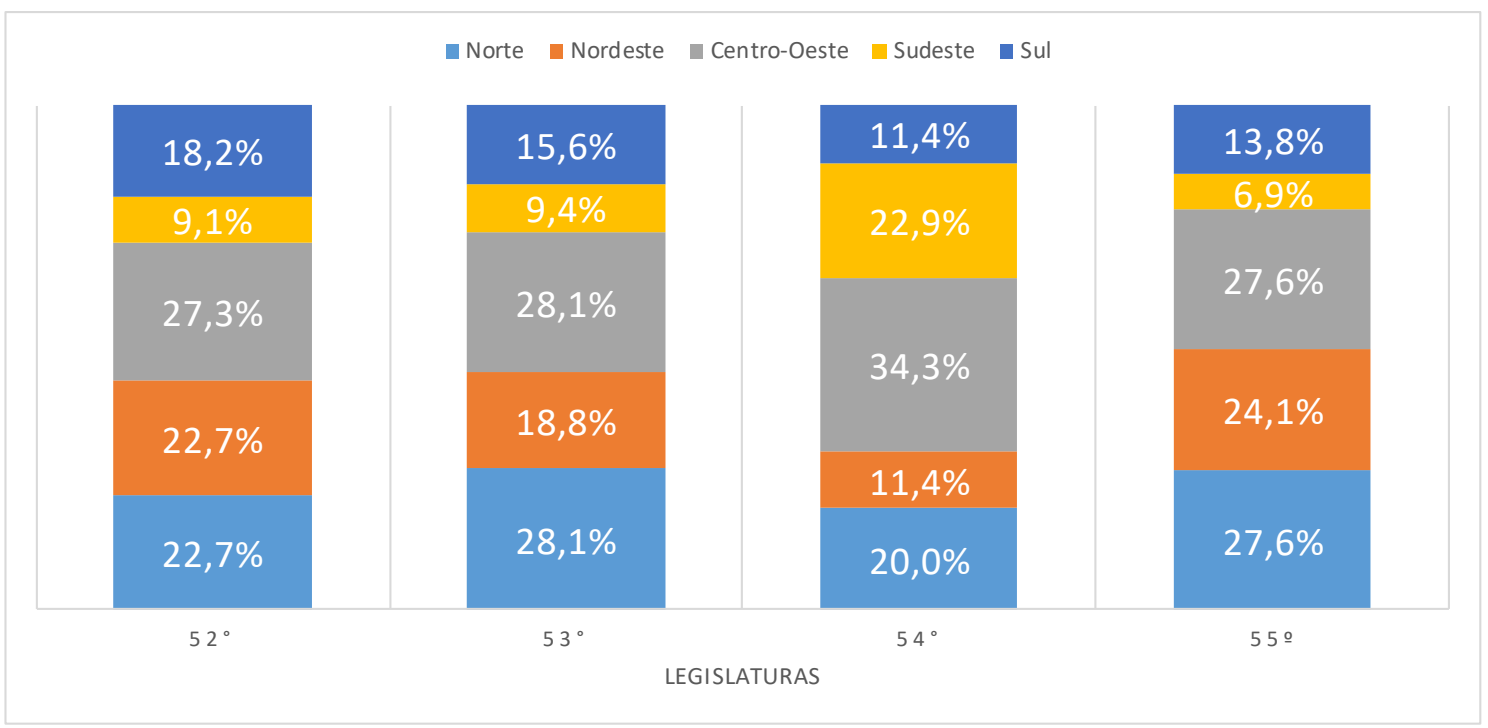

Fonte: Elaboração própria a partir dos Relatórios Anuais da Presidência do Senado Federal

Dessa forma, observa-se que os homens compuseram de forma expressiva a CRA,

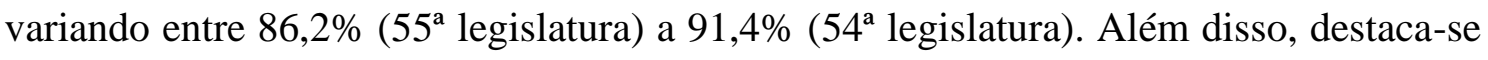
que, verificando o quadro de senadores nas $52^{\mathrm{a}}, 53^{\mathrm{a}}, 54^{\mathrm{a}}$ e $55^{\mathrm{a}}$ legislaturas, no site do Senado Federal, dos 81 senadores, 10, 12, 12 e 13 foram senadoras, respectivamente. Estes resultados confirmam o que aponta a literatura, ou seja, a falta ou pouca representação feminina na atividade política, sendo esta sub-representação prejudicial à democracia plena. Outrossim, estes dados indicam que há possibilidade de existir empecilhos para o ingresso das mulheres na atividade política.

Em seu estudo, Busanello e Rhebein (2017) afirmam ainda que as mulheres tendem a ser "represadas" em comissões sobre temas que são, tradicionalmente, de responsabilidade feminina, como da área da saúde, cuidados com os filhos etc. Isto explicaria, em parte, a baixa participação feminina na CRA. Além disso, as autoras sugerem que, para dirimir esta sub-representação, uma das alternativas seria o estabelecimento de cotas especiais ao público feminino. 
Gráfico 4 - Distribuição por gênero dos membros titulares na CRA entre 2005 a 2018

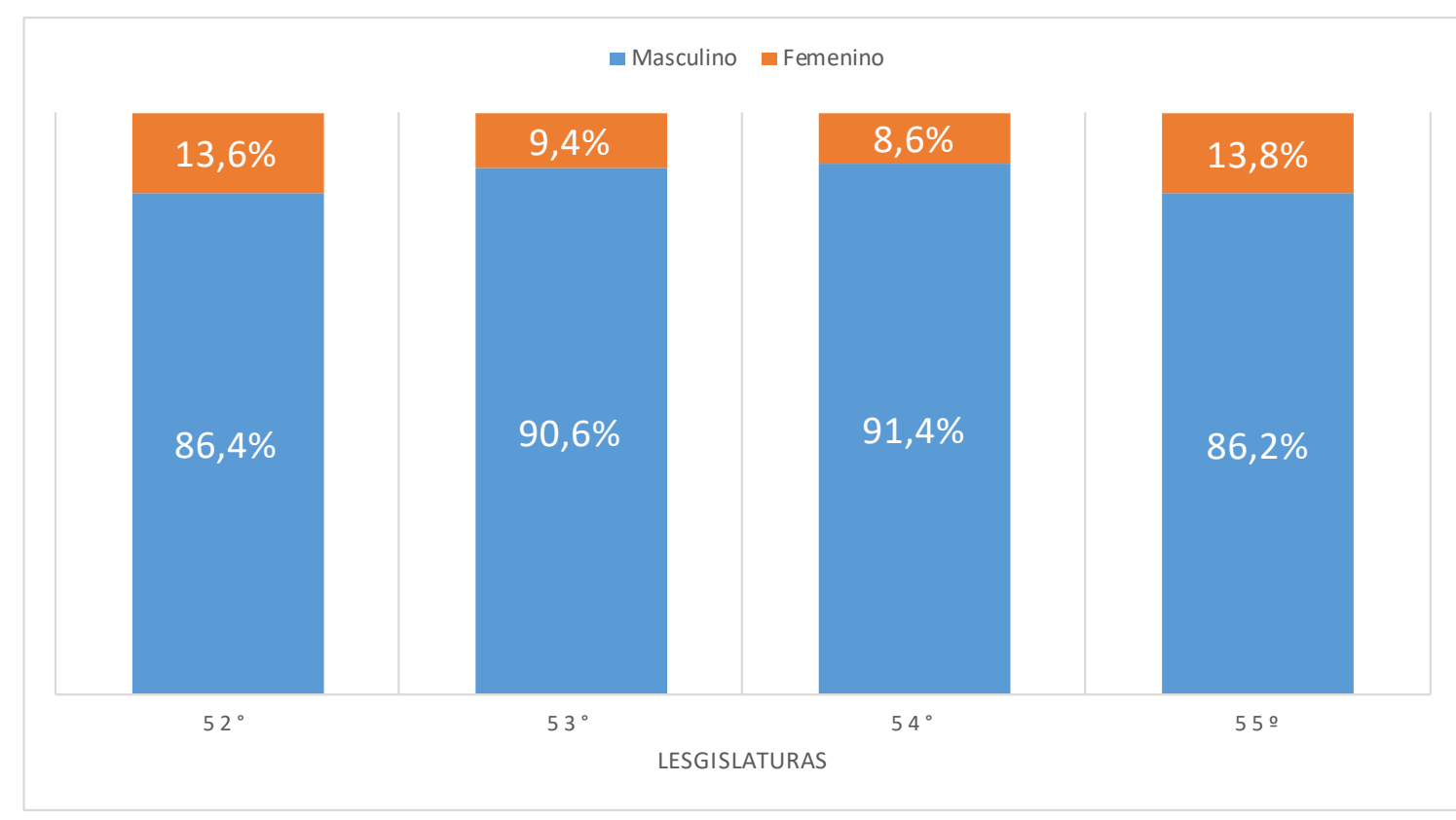

Fonte: Elaboração própria a partir dos Relatórios Anuais da Presidência do Senado Federal

\section{Considerações finais}

Sabe-se que as comissões tomam destaque no processo legislativo, pois se apresentam como um lócus de poder, um espaço importante nas negociações entre o Executivo e o Legislativo. Destaca-se sua competência como poder terminativo, capaz de aprovar ou rejeitar projetos sem a anuência do plenário, além de possuírem a prerrogativa de iniciar, impetrar substitutivos e propor alterações aos projetos de lei, e requerer audiência pública. Outrossim, exercem um papel de fiscalização, de controle, e espaço geracional de informações a respeito das matérias em tramitação. Tal relevância incentiva tanto o Executivo quanto os líderes partidários a captarem comissões leais aos seus propósitos.

Neste texto, foram apresentadas diferentes dimensões a respeito da Comissão da Agricultura e Reforma Agrária do Senado Federal, o propósito deste artigo é fazer a caracterização da CRA, a fim de ampliar o conhecimento sobre a Comissão, e contribuir para a agenda de estudos do sistema brasileiro de comissão. Escolheu-se a CRA pela longevidade e importância dos temas tratados. Portanto, da Comissão foram apresentados: a fragmentação partidária e a relação da coalizão governista e do partido governista; informações de seniority (antiguidade do senador) e expertise: nível de 
escolaridade, experiência profissional, cargos políticos já exercidos, frequência de mandatos assumidos como senadores, tal como quais e em que frequência, os partidos assumiram a presidência e a vice-presidência da CRA; e a origem regional dos senadores e a relação de gênero.

Dessa forma, seguem os principais resultados alcançados pela pesquisa: decerto existe um compartilhamento de poder entre o partido governista e os partidos membros da coalizão, verificou-se que estes últimos mantiveram-se sempre acima de 50,0\% na composição, atingindo o auge de $80,0 \%$ no ano de 2015 , à medida que o PT se demonstrou pouco interessado em ocupar expressivamente a CRA - a taxa máxima de 19,0\% deu-se em 2009 -, todavia, após o impeachment da ex-presidente Dilma, forma-se para a arena legislativa uma nova coalizão, presidida pelo pemedebista Michel Temer, elevando para 25\%, entre 2017 e 2018, o índice de ocupação do partido governista. Este cenário indica que existe a negociação de interesses, desdobrada em trocas de vagas à CRA, tanto entre os partidos que formam a coalizão governista, como entre eles e o partido governista, ou seja, é cedido espaço para articulação política dos membros da coalizão à CRA cujos temas são pertinentes aos seus interesses e, em troca, o partido governista ocupa outros espaços de decisão na área legislativa cujas áreas são consideradas prioritárias à presidência da República/partido governista.

Em se tratando da ocupação dos cargos de presidência e vice-presidência da CRA pelos partidos - cargos que ditam o ritmo de tramitação, definem a relatoria, a pauta que será tratada, enfim, cargos estratégicos para articulação política (SILVA, 2016; AGUIAR, 2013) -, observa-se que foram ocupados sempre pelos partidos membros da coalizão governista ou pelo partido governista, ou seja, não houve espaço para a atuação da oposição em cargos de decisão. A presidência foi assumida pelos partidos PSDB, PMDB, PDT, PP, e a vice-presidência, pelos partidos PL/PR, PMDB, PDT, PFL/DEM e PT.

Outro ponto importante é perceber que a CRA não está sendo empregada como um espaço de desenvolvimento da expertise, ou seja, os senadores, em sua grande maioria, permanecem na CRA entre 2 a 3 anos (40,2\% passaram 2 anos, 11,0\% passaram 3 anos, por exemplo), logo, trata-se de tempo limitado para que houvesse aprofundamento quanto aos conhecimentos dos temas tratados na CRA e, assim, desenvolverem a expertise. Pode-se teorizar que este fluxo entre entrada e saída dos senadores na CRA 
ocorre em decorrência da indicação da liderança partidária, que prioriza os interesses do partido em detrimento aos interesses particularistas dos senadores, em outras palavras, a CRA está sendo instrumentalizada como uma ferramenta estratégica aos interesses partidários, à revelia de interesses distributivistas ou a objetivos informacionais como preconizam Aguiar (2013) e Nascimento (2012).

Os senadores, membros titulares na CRA, apresentaram, em sua maioria, nível superior de escolaridade. Ademais, em grande parte, declararam-se advogados e professores, seguidos por profissões relacionadas ao setor do agronegócio, tais como agropecuaristas, agricultores, pecuaristas, engenheiros agrônomos e médicos veterinários; logo, é de se esperar uma elevada qualidade informacional das proposições tratadas na CRA, visto que estes profissionais são aqueles que estão mais em face à atualidade do que acontece no setor do agronegócio, têm o conhecimento mais acurado sobre os temas. Por outro lado, ao que concerne à experiência política prévia, percebe-se que os senadores, em suas carreiras políticas, exerceram mais cargos na arena Legislativa do que na arena do Executivo. Além disso, grande parte dos membros titulares que ingressaram na CRA encontrava-se em seu primeiro e segundo mandato à senador. Estas informações indicam que, de fato, os líderes partidários consideram a expertise do parlamentar no momento da indicação à CRA tal como afirma a literatura (MÜLLER, 2005; SANTOS, 2006; PEREIRA; MUELLER, 2003).

Em se tratando dos aspectos regionais, nota-se a presença marcante dos senadores do Centro-oeste, este fato pode estar relacionado à especulação do agronegócio que pontua o Centro-oeste como uma fronteira promissora, área ne migração de culturas como colocam Lourenzani e colaboradores (2016), e Filho (2016).

No mais, observa-se que é larga a participação masculina na CRA em relação à feminina, podendo-se considerar que existem barreiras que interferem no ingresso ou no incentivo ao interesse das mulheres em participar da atividade política. Esta conjuntura é reflexo do contexto social brasileiro, que impetra imperativos ditando que as mulheres devem se interessar por assuntos particulares e domésticos, deixando a cargo dos homens as atividades públicas, como sugere Pateman (2013). Dessa forma, alternativas devem ser pensadas com o intuito de minimizar tais desigualdades, uma delas é resguardar cotas 
especiais à participação feminina, e incentivar que elas ocupem tais vagas, além de garantir o acesso a subsídios financeiros públicos, tal como é o Fundo Eleitoral.

Em suma, há de se mencionar que se trata de estudo preliminar, portanto, há questões a serem refletidas, debatidas e respondidas com o andamento da pesquisa, tais como investigar em detalhes o porquê do interesse dos senadores do Centro-oeste em participar da CRA; averiguar o grau de sucesso de sanção presidencial das proposições que tramitam na CRA; saber qual o grau terminativo da CRA; averiguar se a Comissão constrói maiorias consonantes ou discordantes com outras comissões permanentes, tanto do Senado Federal quanto da Câmara dos Deputados; e se a CRA realiza mais reuniões deliberativas ou informacionais. Enfim, estas são algumas, entre tantas indagações, que a pesquisa suscita.

\section{Referências}

ABRANCHES, S. H. Presidencialismo de coalizão: o dilema institucional brasileiro. Dados, Rio de Janeiro, v. 31, n. 1, p. 5-34, 1988.

AGUIAR, O. De O. Os Atores-chave no processo decisório no âmbito das comissões permanentes. E-Legis, v. 6, n.12, p. 137-152, 2013.

AMARAL, A. R. V. P. O parlamento brasileiro: processo, produção e organização legislativa: o papel das comissões em perspectiva comparada. In: NICOLAU, J.; BRAGA, J. de J. Para além das urnas: reflexões sobre a câmara dos deputados. Brasília: Centro de Documentação e Informação/Edições Câmara, 2011, p. 149-177.

ARAÚJO, P. M. A câmara alta no presidencialismo brasileiro: o desempenho legislativo do Senado entre 1989 e 2000. In: LEMOS, L. B. (Org.). O senado federal brasileiro no pós-constituinte. Brasília: Senado Federal; Unilegis, 2008, p. 203-236.

ARAÚJO, P. M. O bicameralismo no Brasil: argumentos sobre a importância do Senado na análise do processo decisório federal. Política\& Sociedade, São Carlos, v.11, n.21, 2012.

BERTHOLINI, F.; PEREIRA, C. Pagando o preço de governar: custos da gerência de coalizão no presidencialismo brasileiro. Revista Administração Pública, Rio de Janeiro, v. 51, n. 4, p. 528-550, 2017.

BRASIL. Congresso Nacional. Relatório da Presidência: Senado Federal/Congresso Nacional. Brasília: Senado Federal, 2015. Disponível em: https://www25.senado.leg.br/ documents/12427/57201/RAP2015/19ba256b-ddf7-447b-9d21-4ed09a6f0cea. Acesso em: $22 / 12 / 2019$.

BRASIL. Congresso Nacional. Relatório da Presidência: Senado Federal/Congresso Nacional. Brasília: Senado Federal, 2016. Disponível em: https://www25.senado.leg.br/ 
documents/12427/464674/RAP2016/72da4531-842b-4166-8ff9-522553587ba7. Acesso em: $22 / 12 / 2019$.

BRASIL. Congresso Nacional. Relatório da Presidência: Senado Federal/Congresso Nacional. Brasília: Senado Federal, 2017. Disponível em: https:/www25.senado.leg.br/ documents/12427/95431209/RAP2017/9c0c6b79-67c9-46fc-8f09-507823067234.

Acesso em: 22/12/2019.

BRASIL. Congresso Nacional. Relatório da Presidência: Senado Federal/Congresso Nacional. Brasília: Senado Federal, 2018. Disponível em: https://www25.senado.leg.br/ documents/12427/96208845/RAP2018/07b79d01-9a70-4a99-9b96-28e0e5305458.

Acesso em: 22/12/2019.

BUSANELLO, E.; REHBEIN, M. As deputadas federais na presidência e vicepresidência das comissões permanentes da câmara dos deputados: quem são elas e como chegaram lá? E-Legis, Brasília, v. 10, n.23, p. 106-132, 2017.

FIGUEIREDO, A.; LIMONGI, F. Instituições políticas e governabilidade: desempenho do governo e apoio legislativo na democracia brasileira. In.: MELO, C. R.; SÁEZ, M. A. (Orgs.). A democracia brasileira: balanços e perspectivas para o século 21. Belo Horizonte: ed. UFMG, 2007, p. 25-32.

FIGUEIREDO, A.; LIMONGI, F. O Poder de agenda na democracia brasileira: desempenho do governo no presidencialismo pluripartidário. In: SOARES, Gláucio; RENNÓ, Lúcio (Orgs.). Reforma política: lições da história recente. Rio de Janeiro: Ed. FGV, 2006, p. 249-280.

FILHO, J. E. R. Expansão da fronteira agrícola no Brasil: desafios e perspectivas. Brasília; Rio de Janeiro: Ipea, 2016.

FREITAS, A. Presidente, coalizão e maioria. In: FREITAS, A. O presidencialismo de coalizão. Rio de Janeiro: Editora Fundação Konrad Adenauer, 2016, p. 60-84.

LEMOS, L. B. O sistema de comissões no senado brasileiro: hierarquia e concentração de poderes nos anos 1990. In: LEMOS, L. B. (Org.). O senado federal brasileiro no pós-constituinte. Brasília: Senado Federal; Unilegis, 2008, p. 351-390.

LIJPHART, A. Modelos de democracia. Rio de Janeiro. Editora Civilização Brasileira, 2008.

LIMONGI, F.; FIGUEIREDO, A. A crise atual e o debate institucional. Novos Estudos Cebrap, São Paulo, v. 36, n. 3, p. 79-97, 2017

LOURENZANI, W. L.; BERNADO, R.; CALDAS, M. M. Produção de biocombustível e alteração da composição agropecuária no Centro-Oeste do Brasil. Interações, Campo Grande, v. 17, n. 4, p. 561-575, 2016.

MÜLLER, G. Comissões e partidos políticos na câmara dos deputados: um estudo sobre os padrões partidários de recrutamento para as comissões. Dados, Rio de Janeiro, v. 48, n. 1, p. 371-394, 2005. 
NASCIMENTO, E. O. O sistema de comissões brasileiro: elementos para uma agenda de pesquisa. Teoria \& Pesquisa, São Carlos, v. 21, n. 2, p. 61-72, 2012.

NEIVA, P. Disciplina partidária e apoio ao governo no bicameralismo brasileiro. Revista Sociologia e Política, Curitiba, v. 19, n. 39, p. 183-196, 2011.

NEIVA, P.; SOARES, M. Senado brasileiro: casa federativa ou partidária? Revista Brasileira de Ciências Sociais, São Paulo, v. 28, n. 81, p. 97-115. 2013.

PARO, J. P. Sistema brasileiro de comissões parlamentares. E-Legis, Brasília, v. 7, n. 15, p. 28-45, 2014.

PATEMAN, C. Críticas feministas a dicotomia público/privado. In: BIROLI, F.; MIGUEL, L. F. (Orgs.). Teoria política feminista: textos centrais. Vinhedo: Horizonte, 2013, p. 55-80.

PEREIRA, C.; MUELLER, B. Partidos fracos na arena eleitoral e partidos fortes na arena legislativa: a conexão eleitoral no Brasil. Dados, Rio de Janeiro, v. 46, n. 4, p. 735-771, 2003.

PEREIRA, C.; MUELLER, B. Uma teoria da preponderância do poder executivo: o sistema de comissões no legislativo brasileiro. Revista Brasileira de Ciências Sociais, São Paulo, v. 15, n. 43, p. 45-67, 2000.

POWER, T. Presidencialismo de coalizão e o design institucional brasileiro: o que sabemos até agora? In: SATHLER, André; BRAGA, Ricardo. (Orgs). Legislativo pós1988: reflexões e perspectivas. Brasília: Edições Câmara, 2015, p. 15-45.

ROCHA, M. M.; BARBOSA, C. F. Regras, incentivos e comportamento: as comissões parlamentares nos países do cone sul. Revista Sociologia Política, Curitiba, v. 16, n. suplementar, p. 93-104, 2008.

RUBIATTI, B. C. Sistema de resolução de conflitos e o papel do Senado como câmara revisora no bicameralismo brasileiro: o caso brasileiro. Revista Brasileira de Ciência Política, Brasília, n. 23, p. 35-74, 2017.

SANTOS, F. Governos de coalizão no sistema presidencial: o caso do Brasil sob égide da constituição de 1988. In: ANASTASIA, F. e AVRITZER, L. (Orgs.) Reforma política no Brasil. Belo Horizonte: Ed. UFMG, 2006, p. 223-236.

SANTOS, F. O poder legislativo no presidencialismo de coalizão. Belo Horizonte: Ed. UFMG; Rio de Janeiro: IUPERJ, 2003.

SILVA, N. O senado federal: estudo do desempenho das comissões de constituição e justiça e de assuntos econômicos nos governos FHC e Lula. Caderno Eletrônico de Ciências Sociais, Vitória, v. 4, n. 1, p. 45-64, 2016.

Recebido em: 20/09/2019.

Aceito em: 06/11/2019. 